\title{
Working to Create Work-Ready Graduates: Successful Transition to the Labor Market and the Role of Co-op
}

\author{
Rosalie Wyonch \\ C.D. Howe Institute
}

This paper investigates whether work-integrated learning (specifically co-op programs) results in higher incomes or other benefits after graduation. Analysis employs linear estimation models of the National Graduate Survey (2013) data and a subset of quasi-experimental data to determine the returns to participation in co-op for different fields of study at both the college and university level, differential effects based on individual characteristics, and the effects associated with non-monetary success in the labor market. Estimates suggest that co-op programs have significant benefits for participants in the form of easing transition to the labor market and higher incomes after graduation and that they may play a role in overcoming wage gaps associated with bias toward individual characteristics (race, gender, immigration status).

Keywords: Education, Labor, Linear Methods, Public Policy, Internship, Work-Integrated Learning

\section{INTRODUCTION}

Successfully transitioning from education to the labor market is a significant challenge. When students enroll in a post-secondary program, they are choosing to spend time and money on improving their skills and knowledge in the hopes of earning higher wages after graduation. Finding a stable, wellpaying job after they graduate can be a daunting and difficult transition and educational institutions provide a myriad of career services to assist them. Integrating work experience into educational programs is one approach to easing transition to the labor market.

Work-integrated learning (WIL) is meant to serve as a bridge from post-secondary education into the labor market. Students gain the knowledge and skills they need in academic studies and subsequently learn to apply those skills in a professional work environment. These programs tend to take longer to complete and may require higher investment in the form of tuition.

This paper investigates whether WIL (specifically co-op programs) results in higher incomes or other benefits after graduation. While there is ample evidence to show that work integrated learning has positive outcomes for students, there is little evidence about differential effects by level of education and field of study. Put simply, most analysis has been performed on data for students at the university level and predominantly in STEM fields. Despite relatively few Canadian research results, work integrated learning has been increasing in popularity. The growth of work-integrated learning and co-op programs has been boosted by federal and provincial government programs in Canada. Results from analyzing data on graduates across the country show that: 
- Co-op programs have significant benefits for participants in the form of easing transition to the labor market and higher incomes after graduation and that they may play a role in overcoming wage gaps associated with bias toward individual characteristics.

- At present, co-op programs in arts, education, and social science do not appear to be as beneficial as the programs in STEM subjects. While co-ops are generally beneficial, the differences between fields of suggests a need for caution in assuming that expanding co-op programs to more individuals or new areas would have the same benefits for new graduates as current co-op programs. The underlying causes of the different results by field of study would be a promising avenue for further research.

Government policy-makers and educational institutions should continue their support for expanding the programs so they are accessible to more students. But should also carefully monitor the results of participating in co-op for students both during school and after graduation to continuously improve and adapt the programs to maximize benefit for individual fields of study.

\section{WORK INTEGRATED LEARNING IN CANADA}

Work-integrated learning (WIL) is a catch-all term for programs of study that involve periods of professional experience in addition to academic course requirements. WIL is meant to serve as a bridge from post-secondary education into the labor market. Students gain the knowledge and skills they need in academic studies and subsequently learn to apply those skills in a professional work environment.

The "work" part of WIL could be co-op positions, internships, field placements, supervised practicums, apprenticeships or engaging students in applied research projects. These programs can be a formal requirement to reach certification (co-ops, apprenticeships, practicums and clinical placements) or they may be in addition to formal academic education (applied projects, internships). Wages paid to students for these placements can also vary significantly with some placements offering near market wages and others being volunteer and unpaid. Student rights to wages for these placements are governed by provincial employment standards legislation or, for students working in a federally regulated sector (banks, mobile network operators, broadcasters, airlines), the Canada Labor Code. Most provincial legislation has some conditions under which students may not be entitled to the minimum wage or other labor protections governing hours of work, overtime, and rest periods (for more information about exemptions by province, see Mandryk, et. al 2014). These standards vary province-by-province but all (except Prince Edward Island) have some form of exemption (either implicit or explicit) from certain employment standards when a person is receiving training for a trade, professional designated field, or as part of an academic requirement.

\section{THE COSTS AND BENEFITS OF WIL}

WIL programs have many perceived benefits for the employers and students that participate. For students, benefits include learning discipline- or industry-specific skills, gaining information to form realistic career expectations and providing context to make academic work more meaningful (Grosjean, 2000; Sattler, 2011). Employers benefit from developing industry-specific workforce skills, streamlined recruitment and screening processes, and the ability to bring in specific talent/skills for short -term needs (Sattler and Peters 2012). As a bridge to post-school employment, WIL also provides students with relevant work experience that can be an advantage over other recent graduates in the labor market.

There are also costs associated with WIL. Post-secondary programs generally take longer to complete when they contain a WIL component. They may also have higher tuition fees and additional course requirements. If WIL placements are not close to a student's home or educational institution, there are additional costs associated with moving and finding accommodations. For students, these costs represent a larger investment in their skills and knowledge at the beginning of their career. Presumably, if students choose to enroll in post-secondary programs with work-integrated learning components, they see the potential future career benefits as worth the cost. Data from the National Graduate Survey (2013) shows 
that co-op participants are more likely to have debt when they graduate but have similar levels of debt to non-participants (Ferguson and Wang 2014). Co-op participants have lower debt 3 years after graduation (Table 1).

Employers may be able to attract technically skilled workers at a lower cost if they are willing to hire inexperienced students and undertake some professional development. Employers can treat WIL terms as extended job interviews and offer full-time positions to the most successful students. The costs of WIL for employers are mostly associated with the time it takes to interview and hire students on an ongoing basis, the time it takes more senior employees to mentor the students, and the uncertainty of the actual skill level of the student being hired. In addition, depending on the type of WIL program, employers may be required to pay close-to-market wages to attract the most talented students, thus diminishing their perceived benefit in hiring a student over a recent graduate. For example, coop students in an Engineering program at the University of Waterloo earned \$14 - \$38 per hour during their work terms in 2018 (uWaterloo, 2018). The average hourly wage for "Natural and applied science" occupations - which includes engineers - was \$36.62 per hour in 2018 (Statistics Canada, 14-10-034001).

While actually taking part in WIL, students may be over-worked or under-paid relative to their abilities, due to a lack of labor protections. In addition, not all types of WIL are comparable in terms of experiences gained by students. The employer could choose not to mentor the student during the WIL term and could simply treat them as a typical short-term contract employee, increasing the employer benefit through decreased cost at the expense of the students' benefit. Due to uncertainty on the part of both the employer and the students, and the possibility that WIL can improve job matching and ease the transition from school to the labor market, there may be a continuing need for government subsidization of WIL salaries to encourage businesses to take part.

To ensure that both employers and students receive the largest possible benefit from participating in work-integrated learning programs, there is a need for clear and transparent information about work placements. There is a role for post-secondary institutions to clarify the expectations on both students and employers that participate in WIL as well as communicating with both to ensure that skills and knowledge taught to students are actually integrated into the work that students do in these placements. An analysis of work-integrated learning in Australian universities found that the aspects of WIL that students feel are most important to their learning broadly aligns with best practice principles identified in research and institutional guidelines. Further, many of the problems and difficulties students experienced in performing certain skills during placement could largely be attributed to poor program design (Jackson 2015).

\section{WORK-INTEGRATED LEARNING: STYLIZED FACTS}

To investigate the effects of work-integrated learning on the employment outcomes of students after graduation, I use data from the National Graduate Survey (NGS) 2013. The NGS surveys graduates about their labor market status, and contains demographic and educational information. It also contains qualitative information about graduates' satisfaction with their program of study and whether their labor market outcomes correspond to their expectations. From these responses, it is clear that coop programs are associated with numerous positive labor market characteristics, but that these benefits vary by type and field of study. Graduates from co-op programs have higher income, are more likely to get a permanent position following school and are less likely to have taken further schooling since graduating (Table 1). 
TABLE 1

DIFFERENCE IN LABOR MARKET OUTCOMES BETWEEN STUDENTS GRADUATION FROM COOP AND NON-COOP PROGRAMS

\begin{tabular}{|c|c|c|c|c|c|c|}
\hline & \multicolumn{2}{|l|}{ Overall } & \multicolumn{2}{|l|}{ College } & \multicolumn{2}{|c|}{ Undergraduate } \\
\hline & Coop & Non-coop & Coop & Non-coop & Coop & Non-coop \\
\hline \multicolumn{7}{|c|}{ Regarding Education } \\
\hline $\begin{array}{l}\text { Graduate would select } \\
\text { same field of study } \\
(\%)\end{array}$ & 77.1 & 75.4 & 75.26 & 73.6 & 78.7 & 74.6 \\
\hline $\begin{array}{l}\text { Additional education } \\
\text { since graduation }(\%)\end{array}$ & 34.6 & 42.7 & 30.0 & 36.9 & 41.7 & 50.1 \\
\hline \multicolumn{7}{|c|}{ First Job After Graduating } \\
\hline $\begin{array}{l}\text { Closely Related to } \\
\text { Field of Study (\%) }\end{array}$ & 56.2 & 40.8 & 56.4 & 46.9 & 56.7 & 33.4 \\
\hline $\begin{array}{l}\text { First job is permanent } \\
(\%)\end{array}$ & 63.6 & 52.6 & 67.7 & 58.0 & 59.4 & 50.9 \\
\hline \multicolumn{7}{|c|}{ Job, 3-years after graduation } \\
\hline $\begin{array}{l}\text { Number of Employers } \\
\text { since graduating }\end{array}$ & 1.28 & 1.36 & 1.26 & 2.39 & 1.36 & 1.43 \\
\hline $\begin{array}{l}\text { Income, Job in survey } \\
\text { week }(\$)^{*}\end{array}$ & 47,900 & 45,000 & 41,700 & 40,900 & 55,200 & 49,300 \\
\hline $\begin{array}{l}\text { Job has extended } \\
\text { health benefits }(\%)^{*}\end{array}$ & 75.0 & 70.0 & 81.5 & 70.5 & 69.4 & 69.4 \\
\hline \multicolumn{7}{|c|}{ Debt** } \\
\hline At Graduation & 8,100 & 13,000 & 11,700 & 10,800 & 14,800 & 14,000 \\
\hline In Survey week & 8,300 & 9,600 & 7,600 & 8,100 & 8,900 & 10,700 \\
\hline \multicolumn{7}{|c|}{$\begin{array}{l}\text { Note: Results that are statistically significant at the } 95 \text { percent level are shown in black, non-statistically } \\
\text { significant results are shown in grey. } \\
\text { *sample restricted to respondents with employment } 3 \text { years after graduation. The survey data for income is } \\
\text { censored above } \$ 100,000 \text {. } \\
* * \text { The survey data for student debt is censored for values above } \$ 25,000 \text {. }\end{array}$} \\
\hline
\end{tabular}

Comparing the average outcomes of graduates, coop programs show significant benefits over noncoop programs. Students graduating from coop programs at both university and college are more likely than their non-coop peers to have their first job be permanent and closely related to their field of study (table 1). Similarly, graduates of co-op programs with employment 3 years after graduation have significantly higher incomes than non-participating peers.

This is, however, likely an over-generalization of benefits. Investigating outcomes by field of study shows that the benefit of coop programs varies with the field of study and the type of educational institution attended (university or college) (Table 2). Graduates of coop programs at universities are more likely to get a first job closely related to their field of study across all fields. College coop graduates, on the other hand, are only significantly more likely to have a first job related to their field of study if their program is in engineering or social science. When considering employment 3 years after graduation, the advantage of coop graduates almost entirely disappears outside of university math, computer science, engineering, and health programs. Graduates of post-secondary coop programs show many benefits when compared to non-coop graduates. Across fields of study and institution type, however, the benefits are less clear. In addition, there are many factors beyond one's program of study that determine employment status after graduation. In the next section, I investigate the effect of coop programs on employment outcomes while controlling for various socio-demographic characteristics. 
TABLE 2

AVERAGE DIFFERENCE BETWEEN COOP AND NON-COOP PROGRAMS BY
INSTITUTION TYPE AND FIELD OF STUDY

\begin{tabular}{|c|c|c|c|c|c|c|c|c|c|c|}
\hline & & & \multicolumn{4}{|l|}{ First Job } & \multicolumn{4}{|c|}{ Job 3-years after graduation } \\
\hline & \multicolumn{2}{|c|}{$\begin{array}{l}\text { Additional } \\
\text { education since } \\
\text { graduation }\end{array}$} & \multicolumn{2}{|c|}{$\begin{array}{l}\text { Closely Related to } \\
\text { Field of Study }\end{array}$} & \multicolumn{2}{|l|}{$\begin{array}{l}\text { First job is } \\
\text { permanent }\end{array}$} & \multicolumn{2}{|c|}{$\begin{array}{l}\text { Closely Related to } \\
\text { Field of Study }\end{array}$} & \multicolumn{2}{|c|}{$\begin{array}{l}\text { Job has extended } \\
\text { health benefits }\end{array}$} \\
\hline & University & College & University & College & University & College & University & College & University & College \\
\hline Education & 9 & -7 & 20 & 3 & 6 & 20 & -10 & 11 & -6 & -13 \\
\hline Arts & -19 & -19 & 22 & 11 & 12 & 17 & 0 & 3 & 5 & 10 \\
\hline Humanities & -33 & -45 & 32 & 14 & -5 & 27 & 10 & 12 & 27 & 13 \\
\hline $\begin{array}{l}\text { Social } \\
\text { Science }\end{array}$ & -12 & -6 & 9 & 18 & -7 & 17 & -3 & 3 & -1 & -9 \\
\hline Business & 9 & 2 & 18 & 0 & 8 & 7 & 7 & 8 & 6 & 2 \\
\hline Science & 2 & -26 & 23 & 10 & 18 & -10 & 6 & -11 & 6 & 14 \\
\hline $\begin{array}{l}\text { Math \& } \\
\text { Comp sci }\end{array}$ & -14 & -5 & 31 & -1 & 2 & 5 & 21 & -8 & 14 & 14 \\
\hline Engineering & -7 & -1 & 13 & 21 & 14 & -1 & 14 & 3 & 5 & 0 \\
\hline Health & -9 & -16 & 25 & -3 & -14 & 14 & 10 & -4 & -1 & -16 \\
\hline
\end{tabular}

Note: Results that are statistically significant at the 95 percent level are shown in black, non-statistically significant results are shown in grey.

\section{ESTIMATING THE RETURNS ASSOCIATED WITH CO-OP PROGRAM PARTICIPATION}

\section{Estimating the Income Returns to Participation in Co-op Programs}

Students choose their post-secondary fields and institutions of study based on their personal preferences, the advice of their peers, parents and teachers, their perceived future earning potential and many other factors. This makes evaluating the returns to education and the effect of cooperative programs difficult. It may be the case that the most high-achieving or able students are the ones who choose to enroll in cooperative education programs, and that doing so gives them a slightly larger advantage than they would have had otherwise: co-op graduates have higher GPAs on average than non-co-op graduates (Finnie and Miyairi 2017). It may also be the case that students enrolling in coop programs may be relatively disadvantaged and the effect of coop is to furnish the grad with relevant work experience and level their odds in the labor market.

To estimate the effect of co-op participation on graduates' incomes 3 years after graduation, I employ two regression methods. First, I use an ordinary least squares regression with income as the dependent variable to estimate the coefficient of interest (binary co-op participation variable) while controlling for sociodemographic characteristics and field of study. Sociodemographic control variables include: gender, age, marital status, number of dependent children, immigration status and race. In addition, dummy variables that indicate a graduate's field of study while in post-secondary and whether they are employed part- or full-time are included as additional controls. Detailed results for these regressions are in Table A1. To determine differential effects by the type of postsecondary institution, the model is run with the full sample of employed graduates and with the subsets of university and college graduates individually.

To investigate whether co-op participation affects graduates wages differently based on individual characteristics, I add interaction terms for each characteristic to the simple linear wage estimation model. In particular, whether a person's gender, ethnicity or immigration status affects their wages 3-years after 
graduation and whether coop participation is an important factor. Results show that participation in co-op effects wages after graduation differently for immigrant, visible minority and female university students (Table A1).

One factor that is not controlled for in the above method is the possibility that sociodemographic characteristics and field of study effect both the likelihood of participating in co-op and labor market outcomes after graduation - a potential selection bias problem. To extend the analysis to control for this possibility, I estimate the likelihood of participating in co-op and use this "propensity" to participate and individual characteristics to match similar individuals in the data. To estimate the likelihood of an individual participating in co-op, I employ a logistic regression where the outcome is a binary co-op participation variable. Dependent variables are covariates that relate to both co-op participation and income after graduation: chosen field of study, type of institution, parents' level of education and sociodemographic characteristics. All covariates are significantly related to participation in co-op with the exception of individuals being a visible minority which is significant at a 10 percent confidence level (Table A2).

To select a subset of the sample data that mimics experimental conditions, I execute a matching algorithm using the "MatchIt" R Package. For each survey respondent that participated in co-op, the algorithm matches a non-participant with the nearest propensity score that did not participate in co-op. The resulting dataset contains 2316 matched pairs after removing unemployed respondents (1158 co-op participants and 1158 non-participants). To validate that the matched dataset mimics a controlled experiment, I calculate the difference in means for the treatment and non-treatment groups for each covariate. This was the case for almost all covariates except for level of education where differences are significant at the 95 percent confidence level (Table A2). At a 99 percent confidence level, I do not reject the null hypothesis that the difference between the two groups is zero for all covariates.

To estimate the effect of participation in co-op on incomes three years after graduation, the OLS regressions are re-run using the matched subset of data. Results for regressions using the matched quasiexperimental dataset are in Table A3. The resulting estimates are generally similar to those from the unmatched regression estimates. But the estimated effect of co-op participation is higher in magnitude when using the quasi-experimental data, suggesting that the effect is likely under-estimated when using the full sample.

\section{Estimating the Effect of Co-op Participation on Non-wage Labor Market Outcomes}

The National Graduate Survey asks respondents for information about their first job after school and their employment during the survey week ( 3 years after graduation). These questions yield information about the security of employment, whether respondents' first job is related to their field of study, and whether or not their job provides extended health benefits, among other things.

I use the responses to these qualitative questions, mapped to binary variables, to analyze whether participating in co-op is associated with a higher likelihood of success in the labor market after school. Estimation employs logistic regressions that control for respondents' observable sociodemographic attributes and their field of study. The coefficient on the co-op variable can be interpreted as the relatively probability of giving a positive response to the question of interest relative to non-participants. Dependent variables are coded as follows:

- First job is permanent: $1=$ yes, $0=$ no

- First job relation to field of study: $1=$ highly related, $0=$ somewhat, not very, or not related

- Employment status, 3 years after graduation: 1 = full time employed, 0 = part time employed or unemployed

- Job offers extended health benefits: $1=$ yes, $0=$ no or unsure

Table A4 shows estimation results for the pooled sample of graduates. Table A5 and A6 show the results for university and college graduates respectively. To investigate if effects differ based on individual characteristics, the analysis is extended to add interaction terms for coop participation with immigration status, gender and race (Table A7). 


\section{RESULTS}

\section{Income Outcomes}

Results from the OLS estimation using the full sample of employed graduates indicates that participating in a co-op program is associated with about $\$ 4,300$ higher income 3 years after graduation, at the university level (Table 3). At the college level, however, participating in co-op does not appear to lead to significantly higher incomes 3 years after graduation. All sociodemographic controls are significantly related to income of graduates 3 years post-graduation.

One factor that is not controlled for in the above models is the possibility that sociodemographic characteristics and field of study effect both the likelihood of participating in co-op and labor market outcomes after graduation. Results from the linear regressions using the restricted matched sample of data show that the effect of participating in co-op is likely slightly underestimated when using unmatched data, though results are quite similar (Table 3). ${ }^{1}$ Co-op participation is linked to a $\$ 4,150$ increase in annual income for university graduates and doesn't have a significant effect on the income of college graduates.

TABLE 3

\section{ESTIMATED EFFECT OF PARTICIPATING IN CO-OP ON INCOMES, 3 YEARS AFTER GRADUATION}

\begin{tabular}{|l|l|l|}
\hline & Unmatched Data & Matched Data \\
\hline All & $\$ 2040(* * *)$ & $\$ 3110(* * *)$ \\
\hline University & $\$ 4,280(* * *)$ & $\$ 4,130(* * *)$ \\
\hline College & $\$ 60$ & $\$ 2160$ \\
\hline $\begin{array}{l}\text { Source: National Graduate Survey } 2013-\text { Public Use Microdata, author's calculations. Results include all } \\
\text { graduates with employment 3 years after graduation. }\end{array}$ \\
$\begin{array}{l}\text { Notes: Statistical significance is coded: }(* * *)>99.9 \% \text { confidence, }(* *)>99 \% \text { confidence, }(*)>95 \% \\
\text { confidence, and }(.)>90 \% \text { confidence. Sample restricted to employed graduates. Sample sizes: all }=7508, \\
\text { university }=4606, \text { college }=2902\end{array}$ \\
\hline
\end{tabular}

\section{Gender, Race and Immigration Status: Co-op and Earnings Gaps}

Next, I investigate whether wage premiums associated with co-op participation are affected by individual characteristics. In particular, whether a person's gender, ethnicity or immigration status affects their wages 3-years after graduation and whether coop participation is an important factor. First, results show that women and immigrants receive lower incomes 3 years after graduation, but that there are some interesting differences by level of education (Figure 1). Visible minority individuals do not appear to be at a significant disadvantage in terms of wages compared to their peers. Immigrant graduates receive wages that are an average of $\$ 2,400$ to $\$ 3,000$ lower than non-immigrants. Women are at the largest disadvantage, and receive incomes about $\$ 6000$ lower than their male peers three years after graduation. 


\section{FIGURE 1 \\ INDIVIDUAL CHARACTERISTICS AND WAGES COEFFICIENTS FROM UNMATCHED GRADUATE DATA}

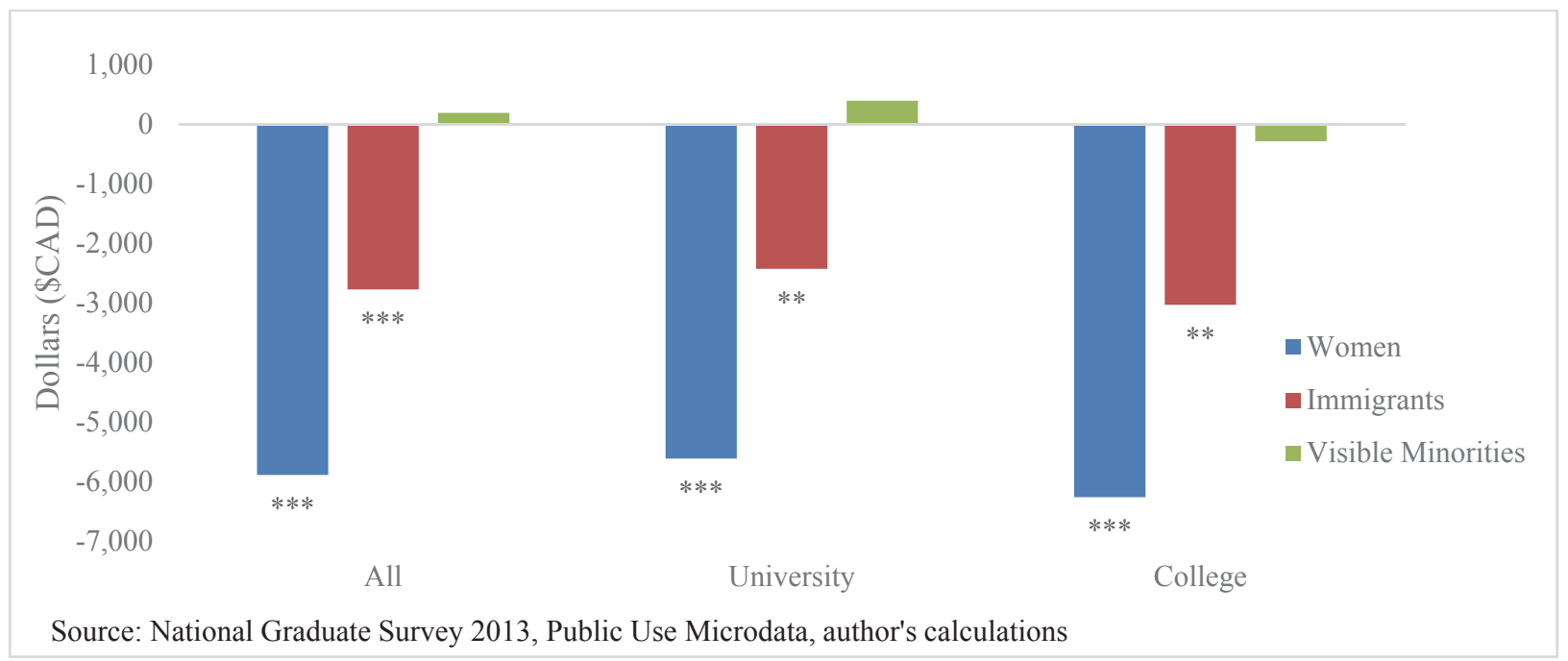

Notes: Statistical significance is coded: $(* * *)>99.9 \%$ confidence, $(* *)>99 \%$ confidence, $(*)>95 \%$ confidence, and (.) $>90 \%$ confidence. Sample restricted to employed graduates (sample size $=7508$ ).

To investigate whether co-op participation affects graduates wages differently based on individual characteristics I add interaction terms for each characteristic to the wage estimation model. Since I am investigating differences that depend on individual's characteristics, these estimations use the unmatched sample of graduates in the labor force. The same estimates are calculated with the matched sample, but most results are weakly or not statistically significant, suggesting that the differences in returns to co-op participation may not be caused by individual characteristics but that these characteristics are associated with varying returns. Results show that participation in co-op effects wages after graduation differently for immigrant, visible minority and female university students (Figure 2). Only the results for the visible minority indicator at the college level and gender are statistically significant.

Visible minorities appear to receive similar income benefits from participating in co-op at the university level compared to white male peers. At the college level, however, visible minority co-op participants make lower incomes than visible minority graduates who didn't participate. Women, already at a disadvantage in terms of income after graduation, receive a lower return to co-op participation than male peers. Female graduates receive wages about $\$ 6000$ lower than male peers. Participating in co-op reduces the disadvantage but does not overcome it - female co-op participants receive incomes about $\$ 3,000$ lower than male peers who do not participate in co-op, all other things equal. 
FIGURE 2

WAGE GAPS AND CO-OP PARTICIPATION, 3 YEARS AFTER GRADUATION

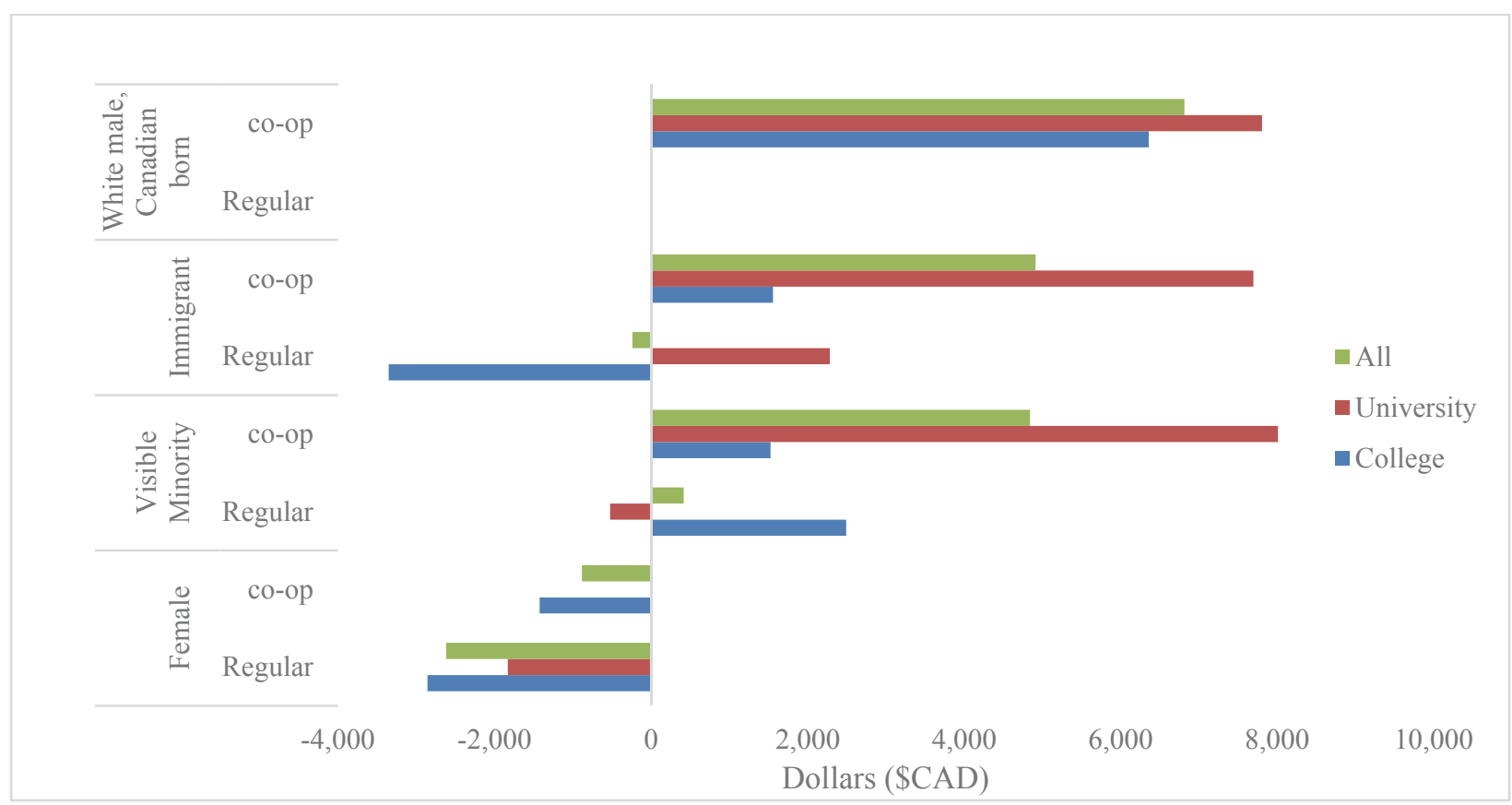

Source: National Graduate Survey 2013, Public Use Microdata, author's calculations

Note: Results include graduates with employment 3 years after graduation. Sample sizes: all $=7508$, university $=$ 4606 , college $=2902$.

Differing returns to participating in co-op programs for different population groups suggest that these programs may play a role in eliminating or reducing wage gaps in the labor market. In particular, visible minority and immigrant individuals who participate in co-op at the university level receive larger returns than their peers and these larger returns are on average sufficient to offset the wage penalty associated with these characteristics. Unfortunately, the opposite appears to be true for women, who receive lower returns to co-op participation than male peers. Women that participate in co-op at the university level, however, receive wages closer to the average across all graduates than non-participating female peers. Further, students that are visible minorities or immigrants are more likely to participate in co-op and women are less likely to participate. Though the estimation method used for this part of the analysis is not sufficient to causally link individual characteristics to different returns to co-op participation, these results suggest that co-op programs could have a moderating effect on wage gaps. Differences in wages and coop participation may be linked to choices in field of study. Co-op programs are over-represented in STEM subjects with relatively few for humanities and arts. The under-representation of women in co-op programs may be an artifact of their under-representation in STEM fields. Further, differences in wages after graduation may relate to individual choices regarding career path or specialty/sub-domain within fields of study.

\section{Income and Field of Study}

The income graduates earn after graduation is linked to their chosen field of study while in school. Students choose their field of study for various reasons including personal interest, individual abilities and potential career paths (with varying levels of income) that could follow education. In this section, I investigate how students' chosen fields of study relate to their incomes after graduation and whether returns to participating in co-op vary with field of study. The previous section investigates links between individual characteristics, co-op participation and income after graduation. Success in the labor market is also dependent on individual's choices. 
To investigate differences in income and co-op participation by field of study, I calculate weighted average participation rates and incomes for each field and level of education (Table 4). Results show, rather unsurprisingly, that graduates that studied business, math, computer science or engineering make higher incomes on average than graduates that studied arts or education. Across all fields of study, only university graduates makes significantly higher incomes after graduation. Results indicate, however, that the increased incomes associated with co-op participation across all fields may be disproportionately driven by particular fields of study. At the college level, students in business or health programs that participate in co-op make lower incomes than non-participating peers.

TABLE 4

CO-OP PARTICIPATION AND INCOME BY FIELD OF STUDY

\begin{tabular}{|c|c|c|c|c|c|c|c|c|c|}
\hline & \multicolumn{3}{|l|}{ All } & \multicolumn{3}{|l|}{ University } & \multicolumn{3}{|l|}{ College } \\
\hline & \multirow{2}{*}{$\begin{array}{l}\text { Co-op } \\
\text { Participation } \\
(\%)\end{array}$} & \multicolumn{2}{|c|}{ Income (\$) } & \multirow{2}{*}{$\begin{array}{l}\text { Co-op } \\
\text { Participation } \\
(\%)\end{array}$} & \multicolumn{2}{|c|}{ Income (\$) } & \multirow{2}{*}{$\begin{array}{l}\text { Co-op } \\
\text { Participation } \\
(\%)\end{array}$} & \multicolumn{2}{|c|}{ Income (\$) } \\
\hline & & Regular & Co-op & & Regular & Co-op & & Regular & Co-op \\
\hline All Fields & 16 & 51,500 & 52,600 & 13 & 54,400 & 60,100 & 25 & 46,000 & 46,100 \\
\hline Education & 9 & 51,700 & 48,500 & 8 & 52,500 & 50,300 & 19 & 45,000 & 43,000 \\
\hline Arts & 11 & 40,200 & 37,800 & 14 & 41,900 & 40,500 & 12 & 37,800 & 33,300 \\
\hline $\begin{array}{l}\text { Social } \\
\text { sciences }\end{array}$ & 12 & 49,500 & 44,600 & 6 & 52,400 & 51,700 & 29 & 37,600 & 39,800 \\
\hline Humanities & 3 & 48,100 & 53,900 & 3 & 49,200 & 58,300 & 7 & 37,800 & 36,700 \\
\hline Business & 21 & 51,400 & 48,800 & 17 & 55,100 & 59,300 & 30 & 44,200 & 39,300 \\
\hline Science & 11 & 48,000 & 53,000 & 9 & 48,200 & 53,100 & 36 & 41,400 & 52,700 \\
\hline $\begin{array}{l}\text { Math and } \\
\text { computer } \\
\text { science }\end{array}$ & 25 & 52,000 & 61,900 & 32 & 56,000 & 66,500 & 19 & 47,300 & 51,200 \\
\hline Engineering & 32 & 57,800 & 63,100 & 35 & 62,900 & 68,100 & 30 & 54,600 & 59,300 \\
\hline Health & 14 & 57,100 & 52,900 & 13 & 64,100 & 65,000 & 18 & 49,100 & 43,600 \\
\hline
\end{tabular}

Note: Results that are statistically significant at the 95 percent level are shown in bold, results that are significant at a 90 percent confidence are shown in black, non-statistically significant results are shown in grey. Includes survey respondents with fulltime employment 3 years after graduation, sample sizes: all $=6483$, university $=4011$, college $=2472$

Source: National Graduate Survey 2013, Public Use Microdata, author's calculations

Science, engineering, math and computer science students receive significantly higher incomes three years after graduation. At the university level, graduates of business and humanities ${ }^{2}$ programs also receive higher incomes on average. Across levels of education, graduates of arts, education, or social science programs receive similar wages whether or not they participated in co-op. At the aggregate level, social science graduates that participate in co-op make significantly lower wages than non-participating peers. At the college level, co-op participants make slightly higher wages but the result is not statistically significant ( $p$-value $=0.22$ ). At the university level, co-op participants make lower wages on average, but 
this result is also not statistically significant ( $\mathrm{p}$-value $=0.82$ ). At the university level, math and computer science students that participate in co-op receive incomes about $\$ 10,500$ more than non-participants, the largest premium for all fields of study. Science, business, and engineering university graduates make about $\$ 4,000$ to $\$ 5,000$ more income 3 years after graduation if they participate in co-op. At the college level, science students participating in co-op receive the most benefit and have incomes about $\$ 11,300$ more than non-participants. One interesting observation from the results in Table 4 is that fields of study associated with larger benefits to participating in co-op also generally have higher levels of participation.

These findings are generally consistent with similar research using different data sources. Finnie and Miyairi (2017) analyzed income tax linked data from 14 Canadian post-secondary institutions and find that degree and diploma graduates that participated in co-op make incomes about $\$ 15,000$ and $\$ 8,000$ higher, respectively, than their non-participating peers after graduation. This analysis also found that the difference in wages for co-op participants and non-participants was largest in the fields of business, engineering, math and computer science at the degree level. Similarly, Finnie and Miyairi found that the co-op wage gap for diploma graduates is highest for math and engineering graduates and that business coop graduates do not receive higher wages than their non-participating peers. After accounting for graduates' grades, the analysis found that earnings premiums associated with co-op were smaller than initial estimates. But, co-op participants outperform non-participants even after accounting for grades.

Whether students decide to participate in co-op or not may be related to the expected increase in income after graduation. It may also be the case that universities and colleges offer more co-op programs in fields of study where co-op is more beneficial for students. About a third of engineering graduates and a quarter of math and computer science graduates participated in co-op at the university level, compared to 16 percent across all fields. Similarly, about 30 percent of science and engineering students at the college level participate in co-op. The link between higher income and co-op participation levels is relatively strong at both the university and college level. ${ }^{3}$ Interestingly, 30 percent of business and social science college graduates participated in co-op but they don't receive significantly higher average incomes than non-participating peers. While there are many reasons to participate in a co-op program beyond the expectation of higher income after graduation, these programs tend to take longer to complete and have higher tuition fees.

\section{Income Impact of Co-op Participation in Summary}

Overall, participating in co-op generally appears to be beneficial for graduates' incomes at the university level - 3 years after graduation co-op participants have incomes about $\$ 2,000$ higher than nonparticipants (Table 3). At the college level, participating in co-op does not necessarily lead to higher incomes after graduation across all fields of study. There are, however, significant benefits to participating in co-op at the college level in science and engineering programs. Aggregate results, however, do not capture underlying and important differences in the effect of participating in co-op that depend on individuals' characteristics and chosen fields of study.

In particular, visible minority individuals who participate in university co-op programs receive larger returns than their peers and these larger returns are generally sufficient to offset the wage penalty associated with race. Similarly, immigrant university graduates who participated in co-op have incomes equivalent to Canadian-born, white male peers who also graduated from a co-op program. Unfortunately, the opposite appears to be true for women, who receive lower returns to co-op participation than male peers. Women that participate in co-op, however, receive wages closer to their male peers than nonparticipating female graduates. Differing returns to participating in co-op programs for different population groups suggest that these programs may play a role in eliminating or reducing wage gaps in the labor market.

Participating in co-op is also associated with different returns to income depending on field of study. Co-op programs in science, engineering math and computer science are associated with larger increases in income 3 years after graduation. Social science, arts, health and education co-op programs, however, are not generally associated with higher incomes after graduation. 
Differences in returns to participating in co-op that depend on individual characteristics and field of study highlight that we cannot assume that expanding co-op programs to more students or into new domains of expertise would necessarily result in similar benefits. University graduates of co-op programs receive higher wages than their non-participating peers, but only 13 percent participate. College graduates make similar average incomes, whether or not they graduated from a co-op program and 25 percent of students participate. The observation that the income benefits of participating in co-op programs may be driven predominantly by graduates of STEM programs, who also receive larger wages on average, highlights that we cannot assume that new co-op programs would result in the same benefit for graduates as current co-op programs. This is especially true if they drastically increase the number of placements or expand programs into new fields of study. This caution is prudent given that results also show that arts, education and social science students do not appear to receive a wage premium after participating in coop.

Success in the labor market, however, is not entirely based on wages. Co-op programs may have additional benefits in terms of learning professional communication skills, gaining information about the labor market and personal career prospects. For international students, attending a Canadian postsecondary institution can be an avenue to permanent residency and co-op programs can help newcomers become familiar with hiring and cultural business practices. Overall, I can conclude that co-op programs are associated with higher wages 3 years after graduation and that the magnitude of benefit is highly influenced by a person's individual characteristics - gender, race and immigration status - as well as their chosen field of study.

\section{Co-op Participation and Non-wage Labor Market Outcomes}

Successful transition to the labor market after school is about more than what graduates earn. In this section, I analyze whether co-op participation is associated with easier entry into the labor market and whether there are perceptible differences for employment 3-years after graduation. The National Graduate Survey asks respondents for information about their first job after school and their employment during the survey week (3 years after graduation). These questions yield information about the security of employment, whether respondents' first job is related to their field of study, and whether or not their job provides extended health benefits, among other things.

To analyze whether participating in co-op is associated with a higher likelihood of success in the labor market after school, I use logistic regressions that control for respondents' observable sociodemographic attributes and their field of study. Regressions use unmatched dataset $(n=8013)$ which contains 4904 responses from university graduates and 3109 from college graduates. For the regression estimating the effect of co-op participation on the likelihood of having extended health benefits provided by an employer, the sample includes graduates with employment 3 years after graduation $(n=7508)$. Results show that across level of education, co-op participants are 56 percent more likely to have their first job be related to their field of study (Table 5). College graduates that participates in co-op were 40 percent more likely to have their first job be permanent that their non-participating peers but there is no statistically significant difference at the university level. The benefits associated with participating in coop do not appear to quickly diminish. Three years after graduation, co-op participants are 42 percent more likely to be employed fulltime and 13 percent more likely to have extended health benefits through work. 
TABLE 5

ESTIMATED EFFECT OF CO-OP PARTICIPATION ON LABOR MARKET OUTCOMES

\begin{tabular}{|l|l|l|l|l|}
\hline & & All & University & College \\
\hline \multirow{2}{*}{ First Job } & Job is permanent & $20.3(* * *)$ & -2.0 & $40.5(* * *)$ \\
\cline { 2 - 5 } & $\begin{array}{l}\text { Job highly related to } \\
\text { field of study }\end{array}$ & $55.8(* * *)$ & $83.4(* * *)$ & $27.9(* * *)$ \\
\hline $\begin{array}{l}3 \text { years } \\
\text { after }\end{array}$ & Employed fulltime & $42.2(* * *)$ & $34.2(* * *)$ & $51.2(* * *)$ \\
\cline { 2 - 5 } Graduation & $\begin{array}{l}\text { Job provides extended } \\
\text { health benefits* }\end{array}$ & $13.4(* * *)$ & $48.5(* * *)$ & $-6.1(* * *)$ \\
\hline $\begin{array}{l}\text { Source: National Graduate Survey 2013 - Public Use Microdata, author's calculations } \\
\text { Notes: Statistical significance is coded: (***) > 99.9\% confidence, }(* *)>99 \% \text { confidence, }(*)>95 \% \\
\text { confidence, and }(.)>90 \% \text { confidence. Sample restricted to graduates in the labor force. } \\
* \text { sample restricted to survey respondents with employment 3 years after graduation. }\end{array}$ \\
\hline
\end{tabular}

Estimates ${ }^{4}$ suggest that women and immigrants are less likely than their peers to have success in the labor market. They are less likely to have their first job after school be a permanent position and are less likely to have extended health benefits 3 years after graduation. Visible minorities are generally less likely than their peers to have their first job be related to their field of study. Women and visible minorities are less likely to be fulltime employed 3 years after graduation. To investigate the effect of co-op participation on labor market outcomes for these population groups, I add interaction terms to the regressions for each characteristic. Results show that participating in co-op is associated with different likelihoods of success in the labor market for men, women, immigrants and visible minorities. Participating in co-op improves the odds of having a graduate's first job be related to their field of study and of being employed fulltime 3 years after graduation for all groups. Results indicate that immigrants and men are more likely to have their first job be permanent if they participate in co-op, but does not substantially improve the odds for women and visible minorities.

Of particular interest is the result that participation in co-op is associated with increased likelihood of being employed fulltime and that the improvements are larger for women, minorities and immigrants than for men (Figure 3). This suggests that participating in co-op may lead to higher labor market attachment and success for these marginalized groups. It could also be the case that people that choose to participate in co-op programs are more career-focused and therefore more likely to be fulltime employed 3 years after graduation, but that does not explain results differing depending on individual characteristics. The analysis method used here cannot say with certainty that co-op is the cause of higher success in the labor market, only that it is associated with improved outcomes. Still, these results suggest that participating in co-op increases the likelihood of successful transition to the labor market and that it may have additional benefits for marginalized groups. 
FIGURE 3

CO-OP PARTICIPATION AND LABOR MARKET OUTCOME GAPS

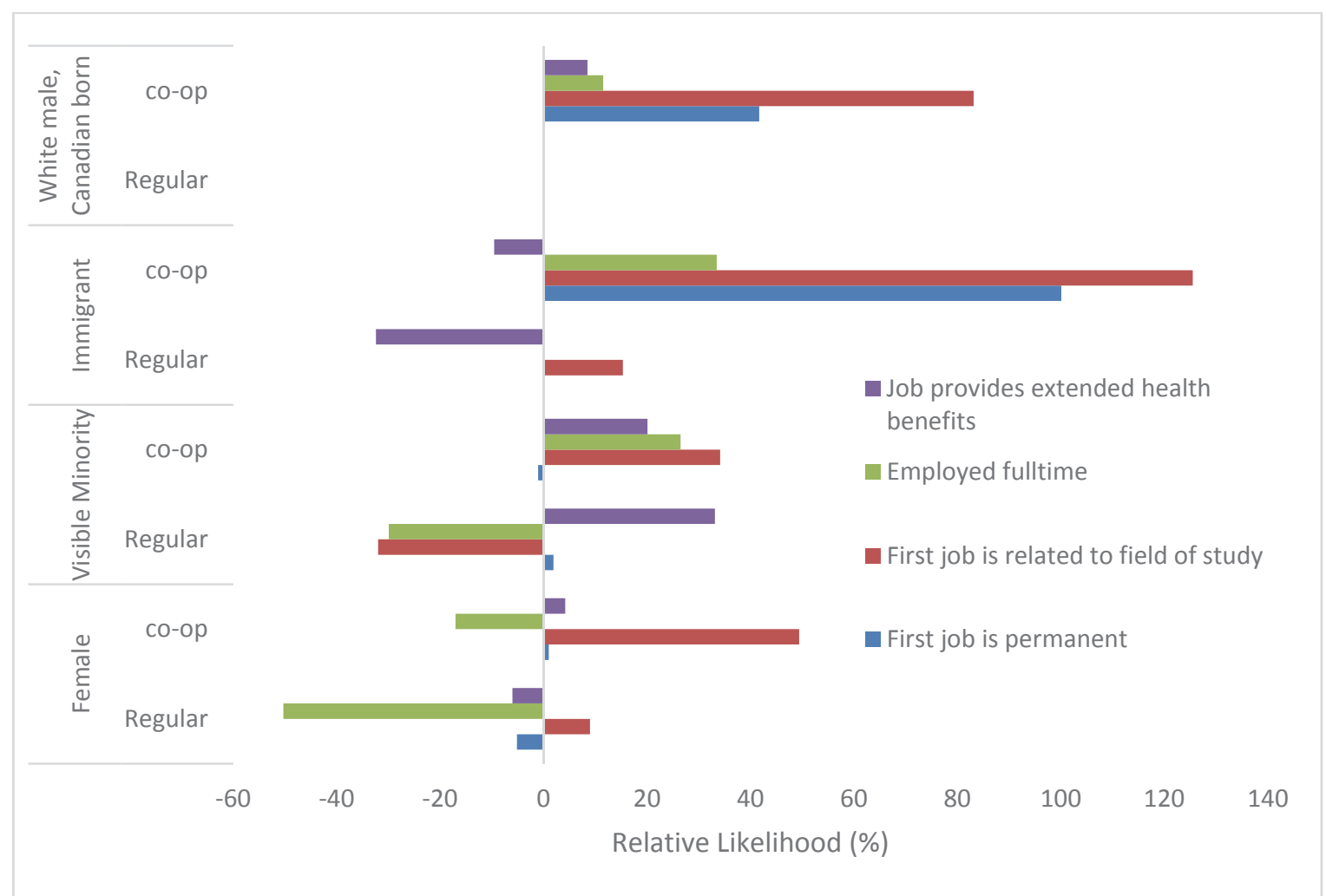

Source: National Graduate Survey 2013 - Public Use Microdata, author's calculations

Notes: Sample restricted to graduates in the labor force for all results except "job provides extended health benefits" which uses the sample restricted to survey respondents with employment 3 years after graduation.

\section{DISCUSSION AND IMPLICATIONS}

Overall, results show that co-op is beneficial to successful transition to the labor market for new graduates in terms of income and gaining fulltime employment that is relevant to their fields of study. Further, co-op participants maintain an advantage in the labor market three years after graduation. There are significant differences in benefits, however, that depend on individual characteristics and areas of study. These differences have important implications for government policies supporting work-integrated learning programs and the potential effects of expanding them into new domains.

Across fields and levels of study, co-op graduates make about $\$ 3,100$ more than non-participating peers, after controlling for individual differences and analyzing a quasi-experimental dataset $(\$ 4,150$ for university graduates and $\$ 2,150$ in income for college graduates, though the result for college graduates is not statistically significant). These positive results, however, hide important underlying differences in expected returns to co-op participation that depend on field of study. For both university and college graduates, participating in co-op is associated with larger incomes 3 years after graduation if they studied science, engineering, math or computer science. Graduates of business programs at the university level have higher incomes if they participated in co-op, but not at the college level. There are no income premiums associated with co-op participation for graduates of education, arts or social science programs. At present, co-op programs in arts, education and social science do not appear to give graduates an advantage in the labor market in terms of income (Table 4). University graduates that studied education, arts or humanities were more likely to have their first job be highly related to their field of study if they participated in co-op (Table 2). 
These results highlight a need for caution in expanding co-op programs to new domains/industries/fields of study. Institutions should not assume that a co-op program that is valuable to students in engineering would be as beneficial to students of other disciplines if it is simply expanded under the same format. Co-op programs may still ease the transition to the labor market for graduates from these fields, as participants are more likely than their peers to have their first job be permanent and related to their field of study (Table 2, Figure 4). In addition, co-op participants are less likely to have gone back to school for additional formal education three years after graduating from arts or humanities programs.

The estimated effect of participating in co-op programs differs for women, visible minorities and immigrants, relative to Canadian men. For visible minority and immigrant university graduates, participating in co-op is associated with similar incomes to white-male co-op participants. At the college level, immigrant graduates that participated in co-op received wages that were higher than non-immigrant peers who did not participate in co-op. Similarly, female co-op participants that graduated from university received wages similar to male peers that did not participate. Immigrants, women and visible minority individuals that participated in co-op were more likely to be employed fulltime than non-participants with similar characteristics. Women, unfortunately, tend to receive lower benefits than men from participating in co-op programs in terms of income and having their first job be related to their field of study or a permanent position.

Together, these results highlight that co-op programs and work-integrated learning more generally may have a role in reducing wage and employment gaps traditionally associated with bias toward individual characteristics. Women that participate in co-op receive wages closer to those of nonparticipating male peers than women who do not participate. For immigrant and visible minority university graduates, the returns from co-op are sufficient on-average to overcome the wage gap. All other things equal, a visible minority university graduate will receive wages about $\$ 500$ lower than their peers. If they participate in co-op, wages increase to $\$ 8,000$ above average and equivalent to the wages of Canadian, Caucasian male university graduates who participate in co-op. Women and immigrants are more likely to participate in co-op than Canadian males. There is not a significant difference in participation between visible minority and Caucasian individuals.

In conclusion, co-op programs have significant benefits for participants in the form of easing transition to the labor market and higher incomes after graduation and that they may play a role in overcoming wage gaps associated with bias toward individual characteristics. Government policy-makers and educational institutions should continue their support for expanding the programs so they are accessible to more students. At present, co-op programs in arts, education and social science do not appear to be as beneficial as the programs in STEM subjects. While co-ops are generally beneficial, the differences between fields of study suggests a need for caution in assuming that expanding co-op programs to more individuals or new areas would have the same benefits for new graduates as current coop programs. This highlights a need to carefully monitor the results of participating in co-op for students both during school and after graduation to continuously improve and adapt the programs to maximize benefit for individual fields of study.

\section{ENDNOTES}

1. One of the underlying reasons for differences between the two results is that the likelihood of participating in co-op is effected by field of study and level of education. Students in math, computer science and engineering are much more likely to participate in co-op programs. Similarly, coop participation is more likely for college students than university students. In the matched sample, there are remaining significant differences between co-op participants and non-participants in select fields of study: engineering and social sciences. While interpretation of the results suggests that there is a wage premium associated with co-op, it may not be purely causal due to underlying differences that cannot be controlled for with the available data. Including field of study as a control variable in the regressions using matched data should be sufficient to control for differences in income by field of study, but cannot separate the effect of coop and field of study. 
2. Results are statistically significant but there are very few humanities graduates who participated in co-op (3 percent). This result may not be generalizable.

3. Correlation between co-op participation rate and the difference in income associated with participation is 0.41 at the university level and 0.59 at the college level. If graduates of humanities programs are removed, the correlation increases to 0.60 across both levels of study ( 0.74 at the university level and 0.66 at the college level).

4. Estimates discussed here use unmatched data for regressions. When using matched data, individual coefficients vary substantially for these control variables which indicates a need for caution against generalizing results

\section{REFERENCES}

Attfield, J., \& Couture, I. (2014). An Investigation into the Status and Implications of Unpaid Internships in Ontario. MPA Dissertation. Victoria: University of Victoria. Retrieved from http://internassociation.ca/academic-articles/

Barry, B., Ohland, M., Mumford, K., \& Long, R. (2016). Influence of Job Market Conditions on Engineering Cooperative Education Participation. Journal of Professional Issues in Engineering Education and Practice, 142(3).

Biss, D.L., \& Pichette, J. (2018). Minding the Gap? Ontario Postsecondary Students' Perceptions on the State of Their Skills. Toronto: Higher Education Quality Council of Ontario. Retrieved from http://www.heqco.ca/SiteCollectionDocuments/Formatted_\%20Student\%20Skills\%20Survey_FI NAL.pdf

Blair, B., \& Millea, M. (2004). Student academic performance and compensation: the impact of cooperative education. College Student Journal, 38(4).

Blundell, R., Dearden, L., \& Sianesi, B. (2001). Estimating the Returns to Education: Models, Methods and Results. London: University College London and Institute for Fiscal Studies. Retrieved from https://core.ac.uk/download/pdf/94278.pdf

CEWIL Canada. (2017). CAFCE Accreditation Standards and Rational. Retrieved from https://www.cewilcanada.ca/_Library/accreditation/CAFCE_Accreditation_Standards_and_Ratio nale_v_April_2017_.pdf

Finnie, R., \& Miyairi, M. (2017). The Earnings Outcomes of Post-secondary Co-op Graduates: evidence from tax-linked administrative data. Ottawa: Education Policy Research Initiative.

Grosjean, G. (2000). Doing Coop: Student Perceptions of Learning and Work. PhD Dissertation, Vancouver: UBC.

Jackson, D. (2015). Employability skill development in work-integrated learning: Barriers and best practices. Studies in Higher Education, 40(2), 350-367. Education Policy Research Initiative.

Mandryk, J., Seaborn, C., Schweda, J., Pinto, S., Kishek, A., Nedyalkova, Y., \& Langille, A. (2014). The Canadian Intern Rights Guide. Canadian Intern Association. Retrieved from http://www.scsu.ca/wp-content/uploads/2014/09/CanadianInternRightsGuide_FINAL_Digital.pdf

Rodriguez, C., Zhao, J., \& Ferguson, S.J. (2016, December 7). Co-op Participation of College and bachelor's graduates. Statistics Canada. Ottawa.

Sattler, P. (2011). Work-Integrated Learning in Ontario's Postsecondary Sector. Toronto: Higher Education Quality Council of Ontario.

Sattler, P., \& Peters, J. (2012). Work-Integrated Learning and Postsecondary Graduates: The Perspective of Ontario Employers. Toronto: Higher Education Quality Council of Ontario.

uWaterloo. (2018). Co-op student earnings information. Retrieved from https://uwaterloo.ca/hire/recruitment-dates-and-procedure/co-op-student-earnings-information

Wessels, W., \& Pumphrey, G. (1995). The effects of cooperative education on job-search time, quality of job placement and advancement. J. Cooperative Educ. Internships, 31(1), 42-52.

Whitten, D. (2013, May 29). Unpaid internships a costly risk. Canadian Employment Law Today, 3. 


\section{APPENDIX - EXTENDED REGRESSION RESULTS}

\section{TABLE A1 \\ ESTIMATION THE INCOME RETURNS TO CO-OP PARTICIPATION, ORDINARY LEAST SQUARES REGRESSION RESULTS}

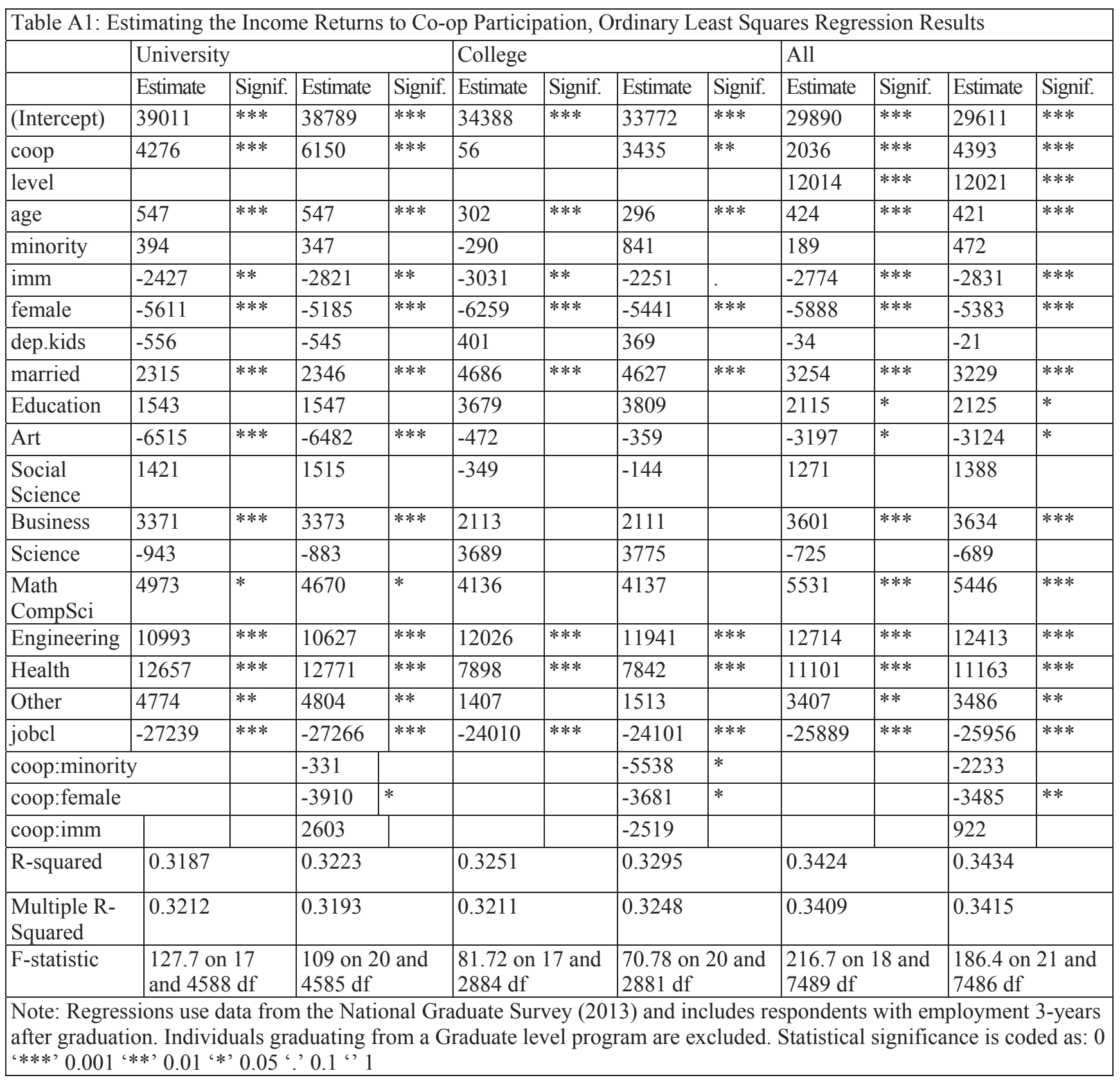

84 Journal of Organizational Psychology Vol. 19(6) 2019 
TABLE A2

SELECTING AND VALIDATING QUASI-EXPERIMENTAL DATASET

\begin{tabular}{|c|c|c|c|c|c|c|}
\hline & \multicolumn{3}{|c|}{ Propensity Score Estimation } & \multicolumn{3}{|c|}{ Covariate Means in Matched Data } \\
\hline & Estimate & Std. Error & z-value & $\begin{array}{l}\text { Non- } \\
\text { participants }\end{array}$ & $\begin{array}{l}\text { Coop } \\
\text { participants }\end{array}$ & $\begin{array}{l}\text { p-value } \\
\text { (difference) }\end{array}$ \\
\hline (Intercept) & -1.89 & 0.05 & -36.22 & & & \\
\hline level & -0.60 & 0.01 & -47.81 & 0.51 & 0.46 & 0.01 \\
\hline age & -0.05 & 0.00 & -41.97 & 26.18 & 25.89 & 0.24 \\
\hline minority & -0.05 & 0.02 & -2.74 & 0.23 & 0.24 & 0.61 \\
\hline imm & 0.35 & 0.02 & 18.39 & 0.18 & 0.19 & 0.53 \\
\hline female & 0.15 & 0.01 & 11.24 & 0.54 & 0.56 & 0.32 \\
\hline mom.ed & -0.05 & 0.00 & -14.53 & 1.75 & 1.61 & 0.07 \\
\hline dad.ed & 0.02 & 0.00 & 5.39 & 1.92 & 1.82 & 0.23 \\
\hline dep.kids & 0.02 & 0.01 & 1.75 & 0.36 & 0.34 & 0.44 \\
\hline married & 0.06 & 0.01 & 4.56 & 0.46 & 0.44 & 0.54 \\
\hline Education & 1.31 & 0.05 & 26.77 & 0.05 & 0.04 & 0.63 \\
\hline Art & 1.11 & 0.05 & 21.20 & 0.02 & 0.03 & 0.16 \\
\hline Social Science & 1.43 & 0.04 & 32.29 & 0.11 & 0.12 & 0.30 \\
\hline Business & 1.95 & 0.04 & 45.34 & 0.30 & 0.30 & 0.95 \\
\hline Science & 1.28 & 0.05 & 24.32 & 0.04 & 0.03 & 0.09 \\
\hline Math.CompSci & 2.25 & 0.05 & 42.46 & 0.04 & 0.03 & 0.78 \\
\hline Engineering & 2.49 & 0.04 & 56.00 & 0.24 & 0.23 & 0.29 \\
\hline Health & 1.52 & 0.04 & 34.34 & 0.12 & 0.14 & 0.12 \\
\hline Other & 1.51 & 0.05 & 31.59 & 0.07 & 0.06 & 0.35 \\
\hline $\begin{array}{l}\text { Number of } \\
\text { Observations } \\
\text { Notes: Regression } \\
\text { labor force. Region } \\
\forall i \in\{\text { coop }=1\}, P\end{array}$ & 8013 & sample of gra & ${ }^{2}$ & $\begin{array}{l}1226 \\
\text { he undergradua } \\
\text { y of the estimat }\end{array}$ & $\begin{array}{l}1226 \\
\text { level that part } \\
\text { distribution: } \\
9,0.486]\end{array}$ & $\begin{array}{l}2452 \\
\text { pate in the }\end{array}$ \\
\hline
\end{tabular}




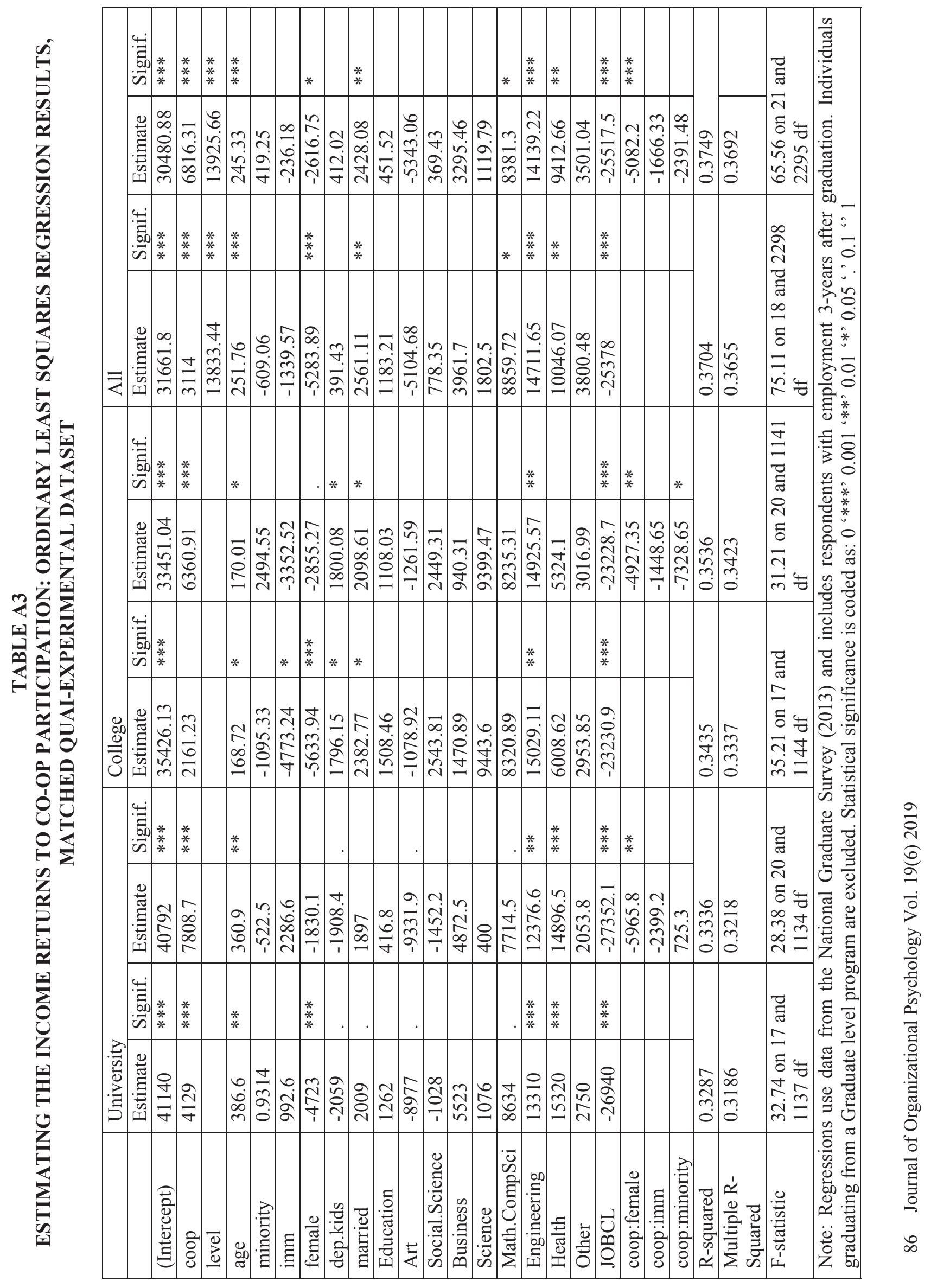


TABLE A4

REGRESSION RESULTS ESTIMATING THE EFFECT OF CO-OP ON NON-WAGE LABOR MARKET OUTCOMES

\begin{tabular}{|c|c|c|c|c|c|c|c|c|}
\hline \multirow[b]{3}{*}{ Coefficients: } & \multicolumn{4}{|l|}{ First Job } & \multicolumn{4}{|c|}{$\begin{array}{l}\text { Job in Survey Week ( } 3 \text { years after } \\
\text { graduation) }\end{array}$} \\
\hline & \multicolumn{2}{|c|}{ Permanent } & \multicolumn{2}{|c|}{$\begin{array}{l}\text { Highly related to field } \\
\text { of study }\end{array}$} & \multicolumn{2}{|c|}{$\begin{array}{l}\text { Extended health } \\
\text { benefits* }\end{array}$} & \multicolumn{2}{|c|}{$\begin{array}{l}\text { Full Time } \\
\text { Employed }\end{array}$} \\
\hline & Estimate & Signif. & Estimate & Signif. & Estimate & Signif. & Estimate & Signif. \\
\hline (Intercept) & 0.23 & $* * *$ & -1.93 & $* * *$ & -0.40 & $* * *$ & 1.44 & $* * *$ \\
\hline coop & 0.20 & $* * *$ & 0.56 & $* * *$ & 0.13 & $* * *$ & 0.42 & $* * *$ \\
\hline Level & -0.14 & $* * *$ & -0.14 & $* * *$ & 0.41 & $* * *$ & 0.41 & $* * *$ \\
\hline age & -0.01 & $* * *$ & 0.05 & $* * *$ & 0.01 & $* * *$ & -0.01 & $* * *$ \\
\hline minority & 0.00 & & -0.32 & $* * *$ & 0.29 & $* * *$ & 0.04 & $*$ \\
\hline imm & -0.08 & $* * *$ & 0.20 & $* * *$ & -0.33 & $* * *$ & 0.14 & $* * *$ \\
\hline female & -0.11 & $* * *$ & 0.02 & . & -0.03 & $* *$ & -0.63 & $* * *$ \\
\hline dep.kids & -0.06 & $* * *$ & -0.06 & $* * *$ & 0.03 & $* * *$ & -0.05 & $* * *$ \\
\hline married & 0.28 & $* * *$ & 0.22 & $* * *$ & 0.43 & $* * *$ & 0.39 & $* * *$ \\
\hline Education & -0.53 & $* * *$ & 0.69 & $* * *$ & 0.50 & $* * *$ & 0.42 & $* * *$ \\
\hline Art & 0.16 & $* * *$ & 0.36 & $* * *$ & -0.17 & $* * *$ & 0.09 & $* *$ \\
\hline $\begin{array}{l}\text { Social } \\
\text { Science }\end{array}$ & 0.00 & & 0.42 & $* * *$ & 0.14 & $* * *$ & 0.40 & $* * *$ \\
\hline Business & 0.66 & $* * *$ & 0.70 & $* * *$ & 0.92 & $* * *$ & 1.03 & $* * *$ \\
\hline Science & -0.48 & $* * *$ & 0.57 & $* * *$ & -0.32 & $* * *$ & 0.07 & $*$ \\
\hline $\begin{array}{l}\text { Math } \\
\text { CompSci }\end{array}$ & 0.48 & $* * *$ & 0.75 & $* * *$ & 0.95 & $* * *$ & 0.97 & $* * *$ \\
\hline Engineering & 0.46 & $* * *$ & 0.98 & $* * *$ & 1.35 & $* * *$ & 2.10 & $* * *$ \\
\hline Health & 0.13 & $* * *$ & 1.41 & $* * *$ & 0.42 & $* * *$ & 0.77 & $* * *$ \\
\hline Other & 0.10 & $* * *$ & 0.64 & $* * *$ & 0.58 & $* * *$ & 0.84 & $* * *$ \\
\hline
\end{tabular}


TABLE A5

REGRESSION RESULTS ESTIMATING THE EFFECT OF CO-OP ON NON-WAGE LABOR MARKET OUTCOMES - UNIVERSITY GRADUATES

\begin{tabular}{|c|c|c|c|c|c|c|c|c|}
\hline \multirow{4}{*}{$\begin{array}{l}\text { Coefficients: } \\
\text { (Intercept) }\end{array}$} & \multicolumn{4}{|l|}{ First Job } & \multicolumn{4}{|c|}{$\begin{array}{l}\text { Job in Survey Week ( } 3 \text { years after } \\
\text { graduation) }\end{array}$} \\
\hline & \multicolumn{2}{|c|}{ Permanent } & \multicolumn{2}{|c|}{$\begin{array}{l}\text { Highly related to } \\
\text { field of study }\end{array}$} & \multicolumn{2}{|c|}{$\begin{array}{l}\text { Extended health } \\
\text { benefits* }\end{array}$} & \multicolumn{2}{|c|}{$\begin{array}{l}\text { Full Time } \\
\text { Employed }\end{array}$} \\
\hline & Estimate & Signif. & Estimate & Signif. & Estimate & Signif. & Estimate & Signif. \\
\hline & -0.365 & $* * *$ & -2.183 & $* * *$ & -0.437 & $* * *$ & 1.442 & $* * *$ \\
\hline coop & -0.020 & & 0.834 & $* * *$ & 0.485 & $* * *$ & 0.342 & $* * *$ \\
\hline age & 0.011 & $* * *$ & 0.050 & $* * *$ & 0.029 & $* * *$ & -0.014 & $* * *$ \\
\hline minority & 0.057 & $* *$ & -0.283 & $* * *$ & 0.487 & $* * *$ & -0.063 & $* *$ \\
\hline imm & -0.273 & $* * *$ & 0.146 & $* * *$ & -0.496 & $* * *$ & -0.230 & $* * *$ \\
\hline female & -0.030 & $*$ & 0.124 & $* * *$ & -0.025 & & -0.416 & $* * *$ \\
\hline dep.kids & -0.034 & $*$ & 0.124 & $* * *$ & -0.085 & $* * *$ & 0.029 & $*$ \\
\hline married & 0.261 & $* * *$ & 0.123 & $* * *$ & 0.596 & $* * *$ & 0.356 & $* * *$ \\
\hline Education & -0.675 & $* * *$ & 0.549 & $* * *$ & 0.427 & $* * *$ & 0.278 & $* * *$ \\
\hline Art & 0.255 & $* * *$ & 0.371 & $* * *$ & -0.406 & $* * *$ & 0.131 & $* * *$ \\
\hline Social.Science & -0.049 & $*$ & 0.234 & $* * *$ & 0.035 & . & 0.344 & $* * *$ \\
\hline Business & 0.814 & $* * *$ & 0.737 & $* * *$ & 1.618 & $* * *$ & 1.228 & $* * *$ \\
\hline Science & -0.462 & $* * *$ & 0.501 & $* * *$ & -0.414 & $* * *$ & 0.085 & $* *$ \\
\hline Math CompSci & 0.633 & $* * *$ & 0.469 & $* * *$ & 0.860 & $* * *$ & 0.819 & $* * *$ \\
\hline Engineering & 0.403 & $* * *$ & 0.826 & $* * *$ & 1.348 & $* * *$ & 1.463 & $* * *$ \\
\hline Health & 0.159 & $* * *$ & 1.277 & $* * *$ & 0.187 & $* * *$ & 0.769 & $* * *$ \\
\hline Other & 0.016 & & 0.541 & $* * *$ & 0.983 & $* * *$ & 0.305 & $* * *$ \\
\hline \multicolumn{9}{|c|}{$\begin{array}{l}\text { Notes: Regressions use data from the National Graduate Survey }(2013) \text { and includes respondents in the labor } \\
\text { force } 3 \text {-years after graduation. Individuals graduating from a Graduate level program are excluded. Statistical } \\
\text { significance is coded as: } 0 \text { '***'0.001 '**, } 0.01 \text { '*' } 0.05 \text { '? } 0.1 \text { ' } 1 \\
\text { *Data restricted to sample of graduated with employment } 3 \text { years after graduation }\end{array}$} \\
\hline
\end{tabular}


TABLE A6

REGRESSION RESULTS ESTIMATING THE EFFECT OF CO-OP ON NON-WAGE LABOR MARKET OUTCOMES - COLLEGE GRADUATES

\begin{tabular}{|l|l|l|l|l|l|l|l|l|}
\hline & \multicolumn{3}{|l}{ First Job } & \multicolumn{3}{l}{ Job in Survey Week (3 years after } \\
graduation)
\end{tabular}

Notes: Regressions use data from the National Graduate Survey (2013) and includes respondents in the labor force 3-years after graduation. Individuals graduating from a Graduate level program are excluded.

*Data restricted to sample of graduated with employment 3 years after graduation for "health benefits"

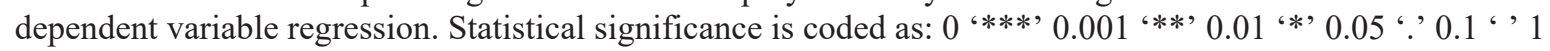


TABLE A7

REGRESSION RESULTS ESTIMATING THE EFFECT OF CO-OP ON NON-WAGE LABOR MARKET OUTCOMES - INDIVIDUAL CHARACTERISTIC INTERACTIONS

\begin{tabular}{|c|c|c|c|c|c|c|c|c|}
\hline & \multicolumn{4}{|l|}{ First Job } & \multicolumn{4}{|c|}{$\begin{array}{l}\text { Job in Survey Week ( } 3 \text { years after } \\
\text { graduation) }\end{array}$} \\
\hline & \multicolumn{2}{|l|}{ Permanent } & \multicolumn{2}{|c|}{$\begin{array}{l}\text { Highly related to } \\
\text { field of study }\end{array}$} & \multicolumn{2}{|c|}{$\begin{array}{l}\text { Extended health } \\
\text { benefits* }\end{array}$} & \multicolumn{2}{|c|}{$\begin{array}{l}\text { Full Time } \\
\text { Employed }\end{array}$} \\
\hline & Estimate & Signif. & Estimate & Signif. & Estimate & Signif. & Estimate & Signif. \\
\hline (Intercept) & 0.061201 & . & -2.0978 & $* * *$ & 0.0325795 & & 1.546429 & $* * *$ \\
\hline coop & 0.416979 & $* * *$ & 0.831504 & $* * *$ & 0.0847643 & $* * *$ & 0.115089 & $* * *$ \\
\hline age & -0.00553 & $* * *$ & 0.046325 & $* * *$ & 0.0102452 & $* * *$ & -0.01529 & $* * *$ \\
\hline minority & 0.019262 & & -0.32012 & $* * *$ & 0.3311545 & $* * *$ & -0.29928 & $* * *$ \\
\hline imm & -0.17575 & $* * *$ & 0.153389 & $* * *$ & -0.3241029 & $* * *$ & 0.002405 & \\
\hline female & -0.05156 & $* * *$ & 0.089633 & $* * *$ & -0.0602522 & $* * *$ & -0.50308 & $* * *$ \\
\hline dep.kids & -0.05548 & $* * *$ & -0.04851 & $* * *$ & 0.0090403 & & -0.11779 & $* * *$ \\
\hline married & 0.270438 & $* * *$ & 0.204523 & $* * *$ & 0.449553 & $* * *$ & 0.385678 & $* * *$ \\
\hline Education & -0.53784 & $* * *$ & 0.688659 & $* * *$ & 0.5037103 & $* * *$ & 0.285607 & $* * *$ \\
\hline Art & 0.203789 & $* * *$ & 0.406823 & $* * *$ & -0.3006086 & $* * *$ & -0.01236 & \\
\hline Social.Science & 0.024668 & & 0.446238 & $* * *$ & 0.0940845 & $* * *$ & 0.418054 & $* * *$ \\
\hline Business & 0.698699 & $* * *$ & 0.745339 & $* * *$ & 0.7947123 & $* * *$ & 0.830551 & $* * *$ \\
\hline Science & -0.47958 & $* * *$ & 0.570823 & $* * *$ & -0.2978306 & $* * *$ & 0.090287 & $* *$ \\
\hline Math.CompSci & 0.540054 & $* * *$ & 0.804454 & $* * *$ & 0.8120771 & $* * *$ & 0.632431 & $* * *$ \\
\hline Engineering & 0.518797 & $* * *$ & 1.029401 & $* * *$ & 1.1450078 & $* * *$ & 1.138822 & $* * *$ \\
\hline Health & 0.203143 & $* * *$ & 1.47906 & $* * *$ & 0.2707312 & $* * *$ & 0.709354 & $* * *$ \\
\hline Other & 0.189579 & $* * *$ & 0.735765 & $* * *$ & 0.3272043 & $* * *$ & 0.444813 & $* * *$ \\
\hline coop:female & -0.35551 & $* * *$ & -0.42684 & $* * *$ & 0.0172461 & & 0.217518 & $* * *$ \\
\hline coop:imm & 0.759933 & $* * *$ & 0.270236 & $* * *$ & 0.1437525 & $* *$ & 0.217256 & $* * *$ \\
\hline coop:minority & -0.44702 & $* * *$ & -0.16996 & $* * *$ & -0.2150591 & $* * *$ & 0.44893 & $* * *$ \\
\hline
\end{tabular}

90 Journal of Organizational Psychology Vol. 19(6) 2019 